\title{
Bathymetry and frontal system interactions influence seasonal foraging movements of lactating subantarctic fur seals from Marion Island
}

\author{
P. J. Nico de Bruyn ${ }^{1, *}$, Cheryl A. Tosh ${ }^{1}$, W. Chris Oosthuizen ${ }^{1}$, Marthán N. Bester ${ }^{1}$, \\ John P. Y. Arnould ${ }^{2}$
}

\begin{abstract}
${ }^{1}$ Mammal Research Institute, Department of Zoology \& Entomology, University of Pretoria, Pretoria 0002, South Africa ${ }^{2}$ School of Life and Environmental Sciences, Deakin University, 221 Burwood Highway, Burwood, Victoria 3125, Australia
\end{abstract}

\begin{abstract}
Sixteen lactating subantarctic fur seals Arctocephalus tropicalis were satellite-tracked during the winter of $2006(n=6)$, summer of 2006/07 $(n=6)$ and autumn/winter $(n=4)$ of 2007, from Marion Island, Southern Ocean. Despite varied individual movement patterns, a favoured foraging area lay to the northeast of the island. In contrast to findings for populations at similar latitudes, seals from Marion Island did not undertake short overnight foraging trips, but trips consistently went beyond $300 \mathrm{~km}$ from the island. This aligns with the at-sea duration of lactating seals' foraging trips from temperate Amsterdam Island, but differs from subantarctic Crozet and Macquarie islands. Time spent at sea, maximum distances travelled and movement variation of tracks from the island varied seasonally. Faecal analysis suggests the diet comprised primarily myctophid fish with limited seasonal variation. Well-defined areas of restricted movement coincided with significant bathymetric features to the west/northwest of the Crozet Plateau, with the Del Caño Rise clearly being important. Positive and negative sea-surface height anomalies (compared to the mean) appeared to be preferred by most seals across seasons. Higher summer sea-surface temperatures correlated with the movements of some seals. Higher chlorophyll a concentrations dictated transit and foraging areas during summer. Bathymetrically influenced oceanographic variables likely explain these preferred long-distance eastward movements. The Îles Crozet and Marion Island subantarctic fur seals differ in their foraging ecology despite being neighbours. Conversely, the subantarctic fur seal populations from the distant Amsterdam and Marion islands appear to be similarly influenced by such environmental factors.
\end{abstract}

KEY WORDS: Otariid $\cdot$ Arctocephalus tropicalis $\cdot$ Foraging ecology $\cdot$ Satellite telemetry $\cdot$ Oceanography $\cdot$ Area-restricted movement $\cdot$ Diet $\cdot$ Del Caño Rise

Resale or republication not permitted without written consent of the publisher

\section{INTRODUCTION}

Marine apex predators have been the focus over the past decade for their role as oceanographic indicators (Fedak 2004, Block 2005, Biuw et al. 2007). However, the complex interplay between frontal systems, bathymetry and other oceanographic variables at a mesoscale and sub-mesoscale are central to the prey habitat preference (Constable et al. 2003) that drives the population dynamics of top predators. Numerous island populations of such predators within the Southern Ocean enabled research pertaining to the ecology and ocean habitats that are utilised by these predators. Otariids (fur seals and sea lions) have been subject to a number of foraging ecology studies and have been successfully used as oceanographic indicators (e.g. Lea \& Dubroca 2003, Ciannelli et al. 2004). Their alternating central place foraging strategies (Orians \& Pearson 1979) during periods of maternal care, and more extensive foraging movements during the non-lactation period (Cherel et al. 2007), make them ideal study templates to address questions of predator foraging ecology and influences of oceanographic variability. However, for a holistic understanding of how environ- 
mental changes dictate the ecology of such predators, studies aimed at identifying foraging areas of several populations of these predators and the prevailing environmental conditions are required. The physical limitations to the extent of any one population's movements necessitate studies on numerous species (and populations) over large temporal and spatial scales.

Subantarctic fur seals Arctocephalus tropicalis have been intensively studied at a few localities in the Southern Ocean. Some studies have focused on comparative foraging ecology of subantarctic and Antarctic fur seals A. gazella at 2 of the 3 island groups where they breed sympatrically, namely Îles Crozet (Bailleul et al. 2005, Luque et al. 2007) and Macquarie Island (Robinson et al. 2002). Both these island systems are situated within the Polar Frontal Zone (PFZ), a diverse and heterogeneous oceanscape in the path of the Antarctic Circumpolar Current (ACC) bounded to the north by the Subantarctic Front (SAF) and to the south by the Antarctic Polar Front (APF) (Lutjeharms \& Valentine 1984). At both these localities, overnight foraging trips comprise a large proportion ( 40 to $50 \%$ ) of the total number of trips during summer, with the longer trips rarely exceeding $10 \mathrm{~d}$ or $100 \mathrm{~km}$ from the particular island (Robinson et al. 2002, Bailleul et al. 2005, Luque et al. 2007). The position of Îles Crozet and Macquarie Island within the productive PFZ is hypothesised as one explanation for the predominance of short overnight foraging trips by those seals. Conversely, subantarctic fur seals at the more temperate Amsterdam Island, far north of the PFZ, have traditionally been portrayed as the 'marathon' seals of the species and research on their long-distance foraging migrations and lengthy at-sea time during attendance cycles have been emphasised (Georges et al. 2000, Beauplet et al. 2004). It is hypothesised that the latitudinal position of Amsterdam Island, far west/northwest of the putative feeding grounds (mostly along the Subtropical Front) necessitates lactating fur seals from there to undertake long, southeast and eastward trips (Beauplet et al. 2004). Clearly, studies of several populations of a species are required to address general questions pertaining to the biology of the species and the extensive ocean habitat that they utilise.

In this respect, foraging studies are lacking for several other localities where subantarctic fur seals occur. The Prince Edward Islands (comprised of Marion Island and the smaller Prince Edward Island) support a large, increasing population of subantarctic fur seals (Bester et al. 2003, Hofmeyr et al. 2006). Aspects of subantarctic fur seal population growth (Hofmeyr et al. 2006, 2007), attendance behaviour (Bester \& Bartlett 1990, Kirkman et al. 2002) and species biology (Kerley 1983, 1985, Bester \& Van Jaarsveld 1994) have been investigated at Marion Island. However, long-range dispersal by subantarctic fur seals based on flippertagged individuals (Bester 1989), and a preliminary technical report on 4 lactating females tracked from the east coast of Marion Island (Osbourne et al. 2002) are the only previous movement studies for the area. These islands support the only other breeding population of the species (aside from Îles Crozet and Macquarie Island) located within the PFZ. Moreover, the Prince Edward Islands are situated along the SW Indian Ridge, a series of undersea mountain ranges and fracture zones or canyons that stretches from the mid-Atlantic Ridge in the west to the central Indian Ridge in the east. These bathymetric features interact with the ACC to form eddies, which enhance the mesoscale variability in this region of the PFZ (Lutjeharms \& Valentine 1988).

Despite the seemingly abundant resources for fur seals in close proximity around the Prince Edward Islands, Kirkman et al. (2002) showed (using attendance patterns data) lengthy at-sea durations for lactating subantarctic fur seals from Marion Island. These at-sea trip durations correspond more closely with those from Amsterdam Island (Beauplet et al. 2004), than with those from the neighbouring Îles Crozet (Bailleul et al. 2005, Luque et al. 2007) or the more distant, but also within the PFZ, Macquarie Island (Robinson et al. 2002). This apparently inconsistent association between the latitudinal position of Marion Island and the duration of time spent at sea forms a central issue in the present study. Furthermore, based on the identification of highly productive foraging areas utilised by other Marion Island predators (Jonker \& Bester 1998, Nel et al. 2001), it is hypothesised that fur seals may forage in similar locations to the west of the island. Several related ecologically important questions arise as a result. (1) Do the subantarctic fur seals from Marion Island feed close to the island owing to the island's location within the PFZ, (2) or do they feed in the same distant area (westwards of the island) as other Marion Island top predators, (3) or eastward, in areas utilised by the neighbouring Îles Crozet, or distant Amsterdam Island, fur seals? (4) Why do they have long winter foraging trips (Kirkman et al. 2002) as do Amsterdam Island fur seals (regardless of their foraging areas)? (5) How does the foraging ecology of the Marion Island fur seal population compare with that at other islands, within the PFZ (Îles Crozet), and away from the PFZ (Amsterdam Island)? (6) Can knowledge of their foraging ecology illuminate potential demographic changes underpinning the recently slowed population growth rate (Hofmeyr et al. 2006) at the Prince Edward Islands?

Foraging studies of lactating females in conjunction with data on prey availability gained from the rate of pup provisioning and growth rate can provide insights 
into the aforementioned demographic changes. For instance, poor foraging conditions often result in longer foraging trips by fur seal mothers and slower pup growth (Boyd et al. 1997, McCafferty et al. 1998, Kirkman et al. 2003, Lea et al. 2006), affecting pup body mass at weaning, which is important for future survival (Beauplet et al. 2005). Therefore, the seasonal at-sea movements of lactating subantarctic fur seal females from Marion Island, incorporating related investigations of diet over concurrent time frames, are employed to address these questions.

\section{MATERIALS AND METHODS}

Study site. Marion Island $\left(46^{\circ} 54^{\prime} \mathrm{S}, 37^{\circ} 45^{\prime} \mathrm{E}\right)$ is situated in the southern Indian Ocean and has a coastline of approximately $107 \mathrm{~km}$, with the nearest landmass being Îles Crozet ( $950 \mathrm{~km}$ to the east; Fig. 1). Although subantarctic fur seals Arctocephalus tropicalis haul out around the entire coast of Marion Island (Hofmeyr et al. 2006), certain focal rookeries are studied here. Breeding adult female fur seals at Van den Boogaard (VdB) and Rockhopper Bay (RhB) colonies on the northeast coast $(<0.1 \mathrm{~km}$ apart; Fig. 1) were selected to study at-sea movements. Due to the small number of seals available at these colonies (VdB and $\mathrm{RhB})$, prey (scats) data was collected from the larger
Cape Davis breeding colony on the north coast (only $\sim 15 \mathrm{~km}$ distant on a similar aspect of Marion Island; Fig. 1). Logistic limitations precluded use of the Cape Davis site for satellite-device deployments. Despite Lea et al. (2008) finding that spatially segregated colonies ( 160 km apart) of Antarctic fur seals at îles Kerguelen foraged in different areas, their diet was superficially similar. The proximity of the different study colonies in the present study thus offers the likelihood that individuals are feeding in similar areas with similar prey. To avoid erroneous conclusions if differences were to exist in foraging areas between colonies, these scat data were used to assess broadscale similarity in prey preferences with other island populations.

Device deployments. At-sea movements were measured during a single foraging trip for each of 16 lactating females during 2006 and 2007, divided between winter, 1 May to 30 September 2006 ( $\mathrm{n}=6$, 2006W); summer, 1 January to 28 February 2007 ( $\mathrm{n}=6$, 2007S); and autumn/winter, 1 March to 30 August 2007 ( $\mathrm{n}=4$, 2007W). Lactating females were selected at random at the $\mathrm{VdB}$ or $\mathrm{RhB}$ colonies and captured with a hoop net. A platform transmitter terminal (PTT; Kiwisat 101, Sirtrack, $120 \mathrm{~g}, 110 \times 42 \times 14 \mathrm{~mm}, 5.7 \mathrm{~cm}^{2}$ cross sectional area) linked to the ARGOS Collection and Location System was attached to the fur on the dorsal midline of the seal immediately posterior to the scapulae, using a

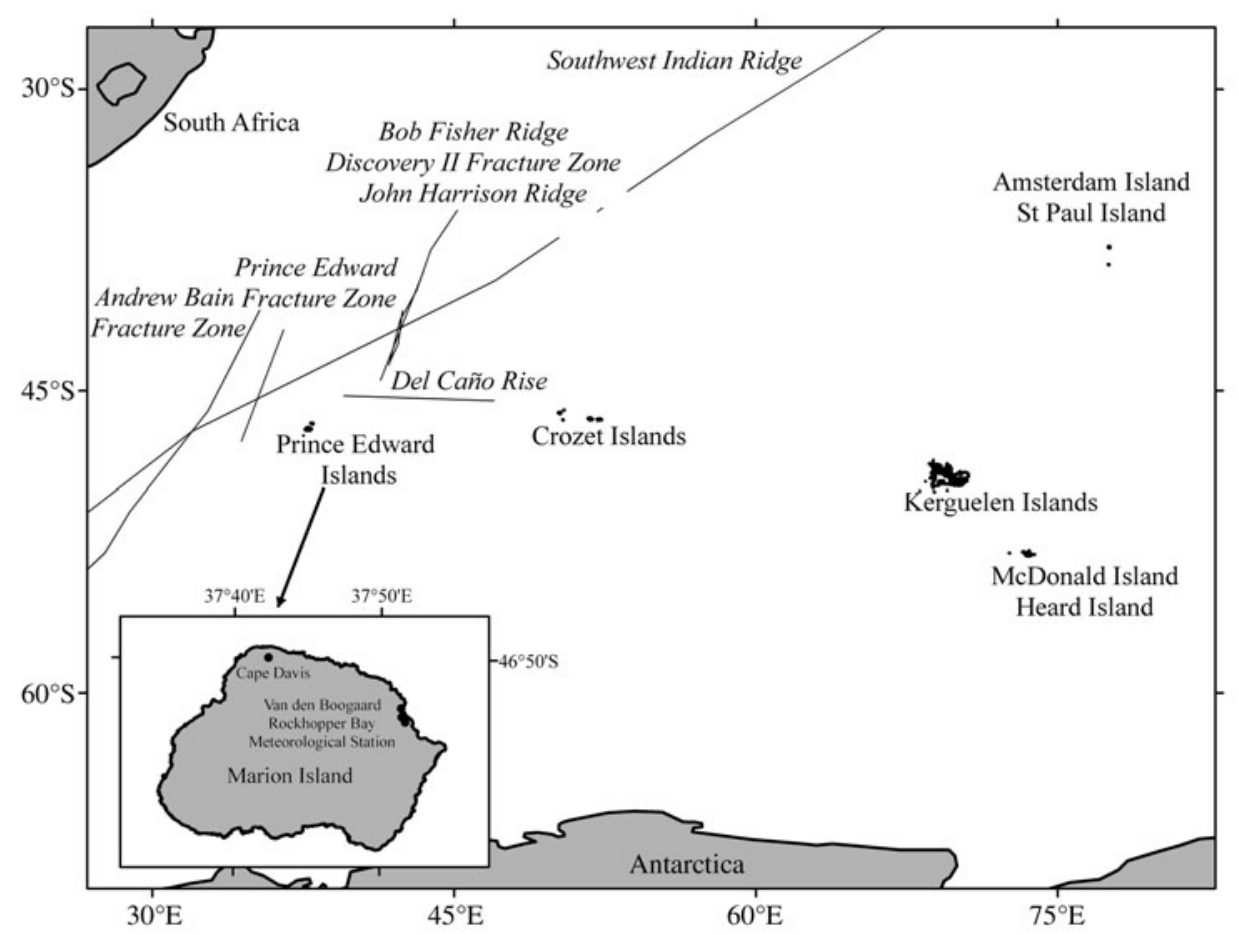

Fig. 1. Location of the Prince Edward Islands in the southern Indian Ocean. Major bathymetric features are presented with names in italics. Insert: Marion Island, depicting the 3 subantarctic fur seal Arctocephalus tropicalis study colonies, namely Van den Boogaard and Rockhopper Bay beaches, where lactating females carried satellite devices, and Cape Davis beach, where scat sampling was done 
double-component, quick-setting epoxy resin (Araldite AW2101, CIBA-GEIGY Ltd.). Upon return from the foraging trip, the seals were recaptured and the devices were removed by careful clipping of the fur underneath. At each of the deployments and retrievals, the restrained seals were released within 30 min of capture. Study females and their pups were marked upon initial capture with uniquely numbered and colour-coded tags (Dalton Jumbo Rototags) at the trailing edge of each fore-flipper, to confirm the successful rearing of pups subsequent to removal of the mother's device and the return of a mother in the unlikely event of the loss of her tracking device.

Data analysis of at-sea movements. ARGOS locations were filtered to exclude those locations that required swimming speeds of $>3 \mathrm{~m} \mathrm{~s}^{-1}$ (Bonadonna et al. 2000), irrespective of the location accuracy value assigned by ARGOS, to avoid excessive data loss (White $\&$ Sjöberg 2002). The filter resulted in the retention of $96 \%$ of the ARGOS locations. Regular trajectories were created by calculating average daily locations (Tosh et al. 2009). Locations were analyzed at a coarser temporal resolution in order to align auxiliary satellite data with our telemetry findings. Maximum distance from the colony and duration of the trips were calculated for each animal. Kernel density probabilities (Silverman 1986) were calculated for each track using least squares cross validation (Seaman \& Powell 1996). Areas of restricted movement (ARM) were identified using a non-parametric kernel density estimator that identified areas of 50 and $95 \%$ probability of occurrence. These core areas of density (50\%) are formed by animals remaining in one place for an extended time relative to the rest of the track. This approach is reliable in this case because the tracks are all regular over time, meaning equal sampling intervals have been created. The remainder of the locations all fell outside of the $50 \%$ probability kernel and were classified as transit locations. The spatial analysis was performed using the Spatial Analyst and Animal Movement Analyst (Hoodge \& Eichenlaub 1997) extensions for ArcView 3.3 (ESRI 1998).

Bathymetric data (IOC IHO, BODC 2003), monthly sea-surface temperature (SST) (MODIS; Feldman \& McClain 2008a), seasonal chlorophyll a (SeaWiFS; Feldman \& McClain 2008b) and daily sea-surface height anomaly (SSHA)/altimetry data (produced by SSALTO/DUACS and distributed by AVISO with support from the Centre National d'Etudes Spatiales) were interpolated using bilinear interpolation to a $1^{\circ}$ grid corresponding to the time period during which the track was recorded. For each altimetry data set, a median date value was selected for interpolation.

All the locations were pooled according to season and classified according to transit type and direction trav- elled. Kruskal-Wallis analysis of variance (ANOVA) was used to test for intra- and inter-seasonal differences in mean values of SST, chlorophyll a concentration, bathymetry and sea-surface height values interpolated to the location data based on transit type and direction travelled. Inter-seasonal variation in SST, chlorophyll a concentration, bathymetry and sea-surface height values was evaluated using Kruskal-Wallis ANOVA.

Diet. Scats were collected from the subantarctic fur seal breeding colony at Cape Davis every month from May to August 2006 and from January to August 2007. Sample sizes were variable due to temporal variation in the numbers of animals ashore. While the breeding colonies are not exclusively used by lactating females, the collection site at Cape Davis consistently included $>90 \%$ lactating females and their pups. Only fresh scats were collected (see Klages \& Bester 1998, for procedure details) and individually processed (see Makhado et al. 2008). Species (identified using sagittal otoliths)-specific regressions were used to estimate prey size and mass, and, for species without published regressions, those of closely related species were used (for details see Makhado et al. 2008). The negative bias in cephalopod beak collection from scats (Ferreira \& Bester 1998, de Bruyn et al. 2003) and the importance of fish in subantarctic fur seal diet at this locality (Klages \& Bester 1998) preclude our use of speciesspecific cephalopod data in the present study. Cephalopod beaks were pooled as 'unidentified' in analyses. For fish, percentage frequency of occurrence was expressed as the number of times each species appeared within all scats containing otoliths, while percentage numerical abundance was the number of otoliths of each species present in all scats. Percentage contribution by mass and number for each species was calculated relative to the mass and number, respectively, of all species found in the scats over time and divided into set time frames (2006W, 2007S, 2007W).

\section{RESULTS}

All 16 fur seals Arctocephalus tropicalis provided tracks of at-sea movements. Duration of tracks (mean \pm $\mathrm{SD})$ varied considerably ( $38 \pm 21 \mathrm{~d}$, range: 14 to $75 \mathrm{~d}$; Table 1). When the incomplete tracks $(n=3)$ were excluded from the analysis, the mean maximum distance attained from the colony was $651 \pm 123 \mathrm{~km}$.

\section{Winter 2006 at-sea movements}

Four seals (S1, S4, S5 and S6) showed similar movements to the northeast of Marion Island (Fig. 2). However, S1 did not return to the island and was thus 
Table 1. Arctocephalus tropicalis. Summary statistics for the at-sea movements of 16 subantarctic fur seals from Marion Island during 2006 and 2007. ARM: area of restricted movement

\begin{tabular}{|c|c|c|c|c|c|c|c|}
\hline Seal ID & $\begin{array}{l}\text { Seal mass } \\
\quad(\mathrm{kg})\end{array}$ & Deployment period & $\begin{array}{c}\text { Track } \\
\text { duration } \\
\text { (d) }\end{array}$ & Season & $\begin{array}{l}\text { Maximum } \\
\text { distance } \\
\text { travelled (km) }\end{array}$ & $\begin{array}{c}\text { Daily distance } \\
\text { travelled }(\mathrm{km}) \\
(\text { mean } \pm \mathrm{SD})\end{array}$ & $\begin{array}{c}\text { Time } \\
\text { spent in } \\
\text { ARM (\%) }\end{array}$ \\
\hline S1 & 30 & 12-26 May 2006 & $14^{\mathrm{a}}$ & Winter & 521 & $12.5 \pm 8.3$ & 36 \\
\hline $\mathrm{S} 2$ & 34 & 1 May-4 Jun 2006 & 34 & Winter & 813 & $33.0 \pm 60.7$ & - \\
\hline $\mathrm{S} 4$ & 36 & 4 May-18 Jun 2006 & 45 & Winter & 515 & $15.0 \pm 28.8$ & 20 \\
\hline S5 & 29 & 10 May-7 Jun 2006 & 28 & Winter & 649 & $23.6 \pm 39.7$ & 57 \\
\hline S3 & 40 & 12 Jun-26 Aug 2006 & $75^{\mathrm{a}}$ & Winter & 1066 & $32.8 \pm 82.2$ & 44 \\
\hline S6 & 37 & 15 Jun-14 Jul 2006 & 29 & Winter & 628 & $24.7 \pm 22.2$ & 62 \\
\hline S7 & 20 & 22 Jan-10 Feb 2007 & 19 & Summer & 437 & $21.7 \pm 14.6$ & 21 \\
\hline $\mathrm{S} 10$ & 26 & 23 Jan-16 Feb 2007 & 24 & Summer & 610 & $17.0 \pm 15.0$ & 21 \\
\hline $\mathrm{S} 13$ & 26 & 2 Feb-3 Mar 2007 & 29 & Summer & 506 & $37.0 \pm 68.0$ & 41 \\
\hline S15 & 36 & 7 Feb-23 Feb 2007 & 16 & Summer & 558 & $30.5 \pm 27.1$ & 50 \\
\hline S8 & 26 & 14 Feb-2 Mar 2007 & 19 & Summer & 377 & $23.4 \pm 22.0$ & 50 \\
\hline $\mathrm{S} 11$ & 26 & 18 Feb-7 Mar 2007 & 17 & Summer & 428 & $22.0 \pm 15.9$ & 41 \\
\hline S14 & 34 & 4-21 Mar 2007 & 17 & Autumn & 318 & $12.0 \pm 8.4$ & - \\
\hline $\mathrm{S} 16$ & 28 & 4-23 Mar 2007 & 19 & Autumn & 617 & $31.1 \pm 39.1$ & 26 \\
\hline S9 & 33 & 14 Apr-23 Aug 2007 & $121^{\mathrm{a}}$ & Winter & 1252 & $26.4 \pm 32.0$ & 36 \\
\hline $\mathrm{S} 12$ & 30 & 31 May-23 Jun 2007 & 23 & Winter & 395 & $24.6 \pm 23.8$ & 43 \\
\hline
\end{tabular}

excluded from further analyses. The 3 remaining seals all moved through cooler waters (Transit SST $=6.4 \pm$ $1.3^{\circ} \mathrm{C}$ ) and displayed localized movements in areas of warmer water $\left(\mathrm{ARM} \mathrm{SST}=8.3 \pm 2.4^{\circ} \mathrm{C}\right.$ ). These animals remained within the ACC and did not cross over the SAF (Fig. 2A). The seals showed concentrated foraging movements across the Del Caño Rise and turned around just short of a clustered group of bathymetric features (Figs. 2B \& 3A). These seals also frequented areas of higher ocean altimetry (sea-surface height$\mathrm{ARM}=6.3 \pm 2.5 \mathrm{~cm}$; Transit $=5.0 \pm 3.2 \mathrm{~cm}$; Fig. $2 \mathrm{C}$ ) Seal S2 travelled to the west of the island directly over the intersection of the SW Indian Ridge and the Andrew Bain Fracture Zone. This seal did not display a specific ARM. Along its path it encountered colder water (SST $=5.9 \pm 1.2^{\circ} \mathrm{C}$ ) and lower, more variable altimetry (sea-surface height $=-1.9 \pm 8.1 \mathrm{~cm}$ ) than seals that travelled northeast. Seal S3 displayed a meandering track that closely followed an area of higher chlorophyll concentration associated with the subtropical Front (STF), but never returned to Marion Island, and was thus excluded from further analyses.

\section{Summer 2006/2007 at-sea movements}

All 6 seals tracked during the summer in early 2007 returned to the island. The mean duration of trips was $20 \pm 5$ d (range: 16 to $29 \mathrm{~d}$ ), and the maximum distance attained from the colony was $486 \pm 88 \mathrm{~km}$ (range: 377 to $610 \mathrm{~km}_{\text {; }}$ Table 1).

Three seals (S8, S10 and S11) were tracked in a northeasterly direction (Fig. 2). In contrast to the
2006W movements, these seals travelled north of the SAF towards the STF, encountering higher SSTs, especially in ARMs (Transit SST $=8.5 \pm 1.5^{\circ} \mathrm{C}$; ARM SST $=$ $10.4 \pm 1.0^{\circ} \mathrm{C}$; Fig. 2A). These seals travelled over the Del Caño Rise (Fig. 2B) and moved in the same area of bathymetric features as the fur seals tracked in the winter period of 2006 (Figs. 2B \& 3C). These areas of warmer waters also coincided with regions of higher altimetry (sea-surface height - Transit $=0.7 \pm 6.4 \mathrm{~cm}$; $\mathrm{ARM}=7.4 \pm 3.7 \mathrm{~cm}$ ). The remaining 3 summer tracks displayed varied patterns. Seal S13 travelled due west, crossing over the SW Indian Ridge and the Prince Edward Fracture Zone. A visual assessment shows that this seal travelled to an area of higher sea-surface height (Fig. 2C) and correspondingly higher chlorophyll a concentrations (Fig. 2D). Seal S15 travelled exclusively along the SAF, seemingly following a path characterized by homogenous SSTs (Transit SST = $\left.7.9 \pm 0.5^{\circ} \mathrm{C} ; \mathrm{ARM} \mathrm{SST}=8.1 \pm 0.7^{\circ} \mathrm{C}\right)($ Fig. $2 \mathrm{~A})$, heterogeneous sea-surface heights (Fig. 2C) and slightly higher chlorophyll a concentrations (Fig. 2D). Seal S7 travelled in a southerly direction to substantially colder waters (Transit SST $=5.7 \pm 0.9^{\circ} \mathrm{C} ; \mathrm{ARM} \mathrm{SST}=3.9 \pm$ $\left.0.06^{\circ} \mathrm{C}\right)$.

\section{Autumn/winter 2007 at-sea movements}

During the autumn/winter period of 2007, 3 of the 4 seals tracked (S12, S14 and S16) returned to the island (Fig. 2). The mean trip duration for these 3 animals was $19.7 \mathrm{~d}$ (range: 17 to $23 \mathrm{~d}$ ). They reached a mean maximum trip distance of $443 \mathrm{~km}$ from the island (range: 

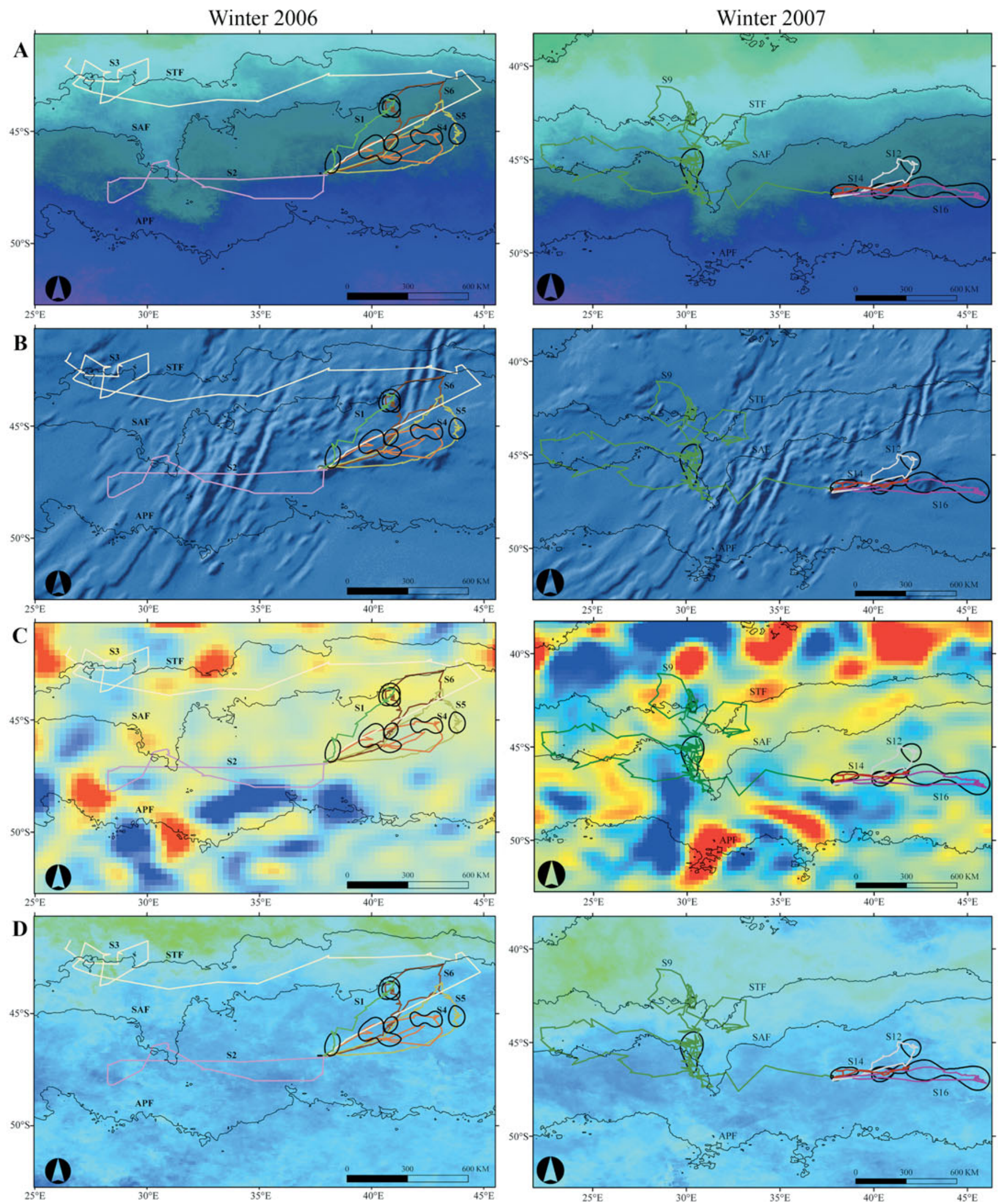

Fig. 2. Arctocephalus tropicalis. At-sea movement of lactating subantarctic fur seals in relation to Marion Island during winter 2006, winter 2007 and summer 2007. Areas of restricted movement are indicated by ellipsoids with: (A) sea-surface temperature overlay, (B) bathymetry overlay, (C) sea-surface height overlay and (D) chlorophyll a overlay. STF: Subtropical Front; SAF: Subantarctic Front; APF: Antarctic Polar Front; seal identification numbers, see Table 1 

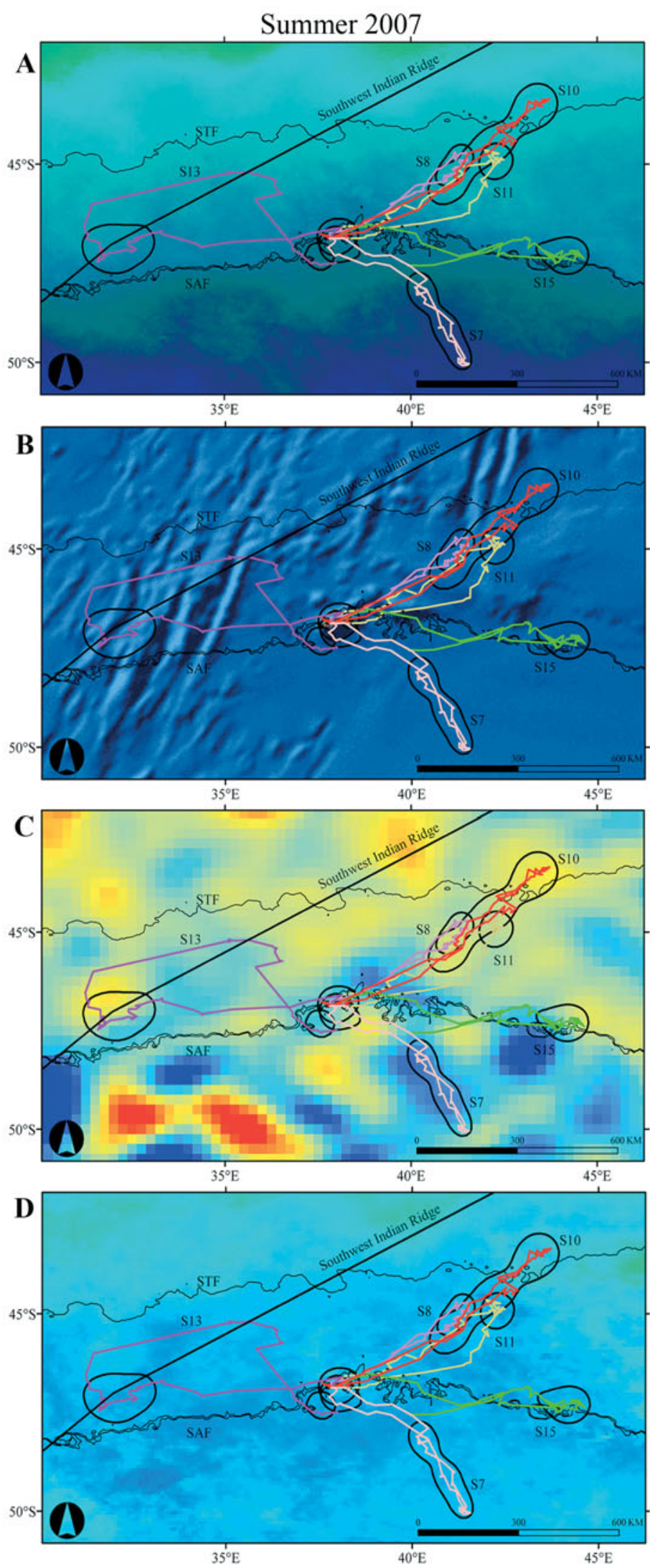

Fig. 2 (continued)

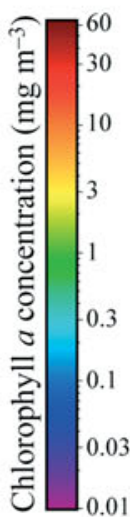

318 to $617 \mathrm{~km}$ ). The remaining seal (S9) travelled for $121 \mathrm{~d}$, reaching a maximum distance of $1251.79 \mathrm{~km}$ from Marion Island, but never returned and is thus excluded from further analyses.

Two of the seals (S14 and S16) travelled due east of Marion Island and encountered uniform SSTs throughout (Transit SST $=8.0 \pm$ $0.6^{\circ} \mathrm{C}$; ARM SST $=8.3 \pm 0.2^{\circ} \mathrm{C}$; Fig. 2A). Seal S12 travelled northeast to the Del Caño Rise (Figs. 2B \& 3B) and encountered colder SSTs .03 (Transit SST $=5.5 \pm 0.5^{\circ} \mathrm{C}$; ARM SST $=6.0 \pm$ $0.4^{\circ} \mathrm{C}$ ) than S14 and S16 (Fig. 2A). All 3 animals travelled within the ACC, not crossing the SAF (Fig. 2A), and different individual ARMs were more widely separated than in the summer or previous winter (Fig. 3). These 3 seals appeared to seek regions of lower altimetry (Fig. 2C).

\section{Comparison of seasonal at-sea movements}

There was no significant difference (Kruskal-Wallis ANOVA, non-parametric test between groups [see figures for all test statistics]) between the seasons for trip duration or maximum distance (Fig. 4A,B). Significant differences (Fig. 5A to D) exist between all the environmental variables for ARM locations for the different seasons. Comparisons amongst all the variables for transit locations for the different seasons were also significantly different (Fig. 5). Locations recorded to the west of the island had significantly deeper water $(-4491 \pm 1032 \mathrm{~m})$ than did locations recorded to the east $(-2450 \pm 1066 \mathrm{~m})$ of the island (Mann-Whitney $U$-test, $Z=14.53$, $5 \mathrm{p}<0.00)$.

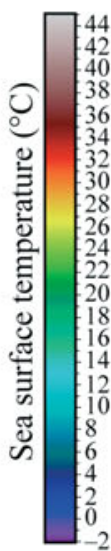

\section{Diet}

Only mesopelagic fishes and a low abundance of cephalopods were detected in scat samples (Table 2). Gymnoscopelus bolini was the most important prey item throughout the study. Although several species, e.g. Electrona antarctica, Krefftichthys anderssoni, Protomyctophum tenisoni and P. choriodon, were frequently encountered as prey items in the scats, their relative mass contribution to the diet was less than that of $G$. bolini throughout (Table 2). G. piabilis and G. nicholsi contributed $28 \%$ of the remaining $44 \%$ of seal 

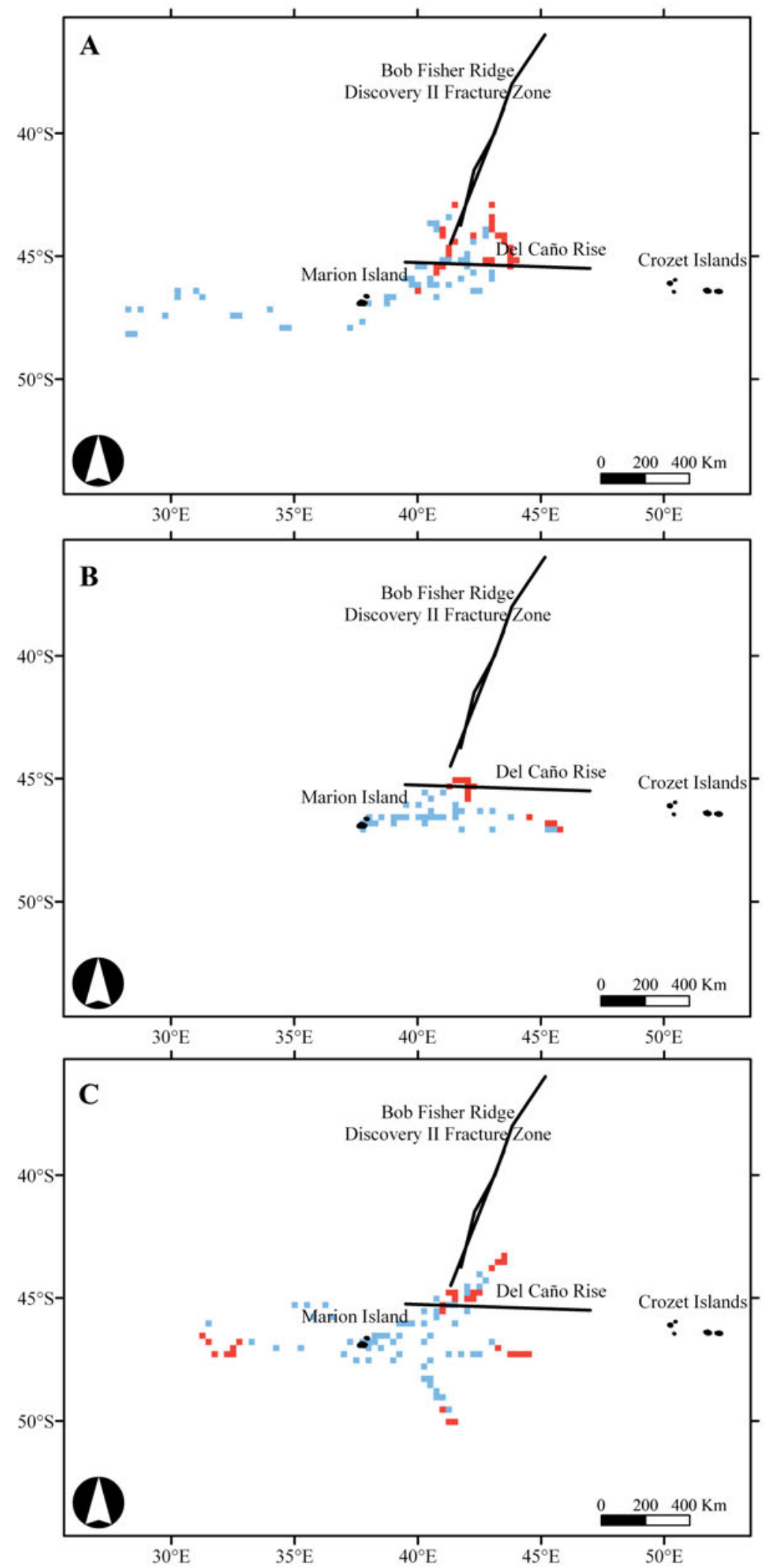

Fig. 3. Arctocephalus tropicalis. Relative position of locations within areas of restricted movement (ARMs; red) to transit locations (blue) for: (A) winter 2006, (B) winter 2007 and (C) summer 2007 prey mass other than $G$. bolini overall. Restricted sample sizes precluded comparison amongst the seasons of the present study, although some differences were evident (Table 2). Females appeared to utilise more (by mass) G. piabilis during later stages of lactation (autumn/winter 2007) as compared with early lactation (summer 2006/2007). Similarly, albeit at levels of comparatively less importance, the mass contribution of Metelectrona ventralis was higher during summer than during both winter periods.

\section{DISCUSSION}

The preferred long-distance eastwardly movement of lactating subantarctic fur seals Arctocephalus tropicalis from Marion Island stands in contrast to the expected behaviour. First, other top predators from Marion Island moved predominantly westward (e.g. Jonker \& Bester 1998, Nel et al. 2001). Secondly, while subantarctic fur seals at the 2 other localities in the PFZ (Îles Crozet and Macquarie Island) feed within close proximity of these islands $(<100 \mathrm{~km})$, the seals from Marion Island feed at a great distance from their island rookeries $(>400 \mathrm{~km})$.

\section{Inter-specific Marion Island comparisons}

Oceanic areas of high productivity preferred by certain top predator species may be preferable for other species even if their foraging ecologies differ (Bost et al. 2009). Southern elephant seals Mirounga leonina consistently travel to the west and southwest of Marion Island (Jonker \& Bester 1998), and recent data (M. N. Bester unpubl. data) correlate many of these westward movements with the Andrew Bain Fracture Zone. Similarly, greyheaded albatross Thalassarche chrysostoma concentrate their foraging in the same area (Nel et al. 2001). Notwithstanding the diverse foraging ecologies of these predators, the overlapping foraging area around the Andrew Bain Fracture Zone provides evidence for an area of productivity that could be attractive to other top predators. However, the evidence in the present study suggests otherwise for sub- 

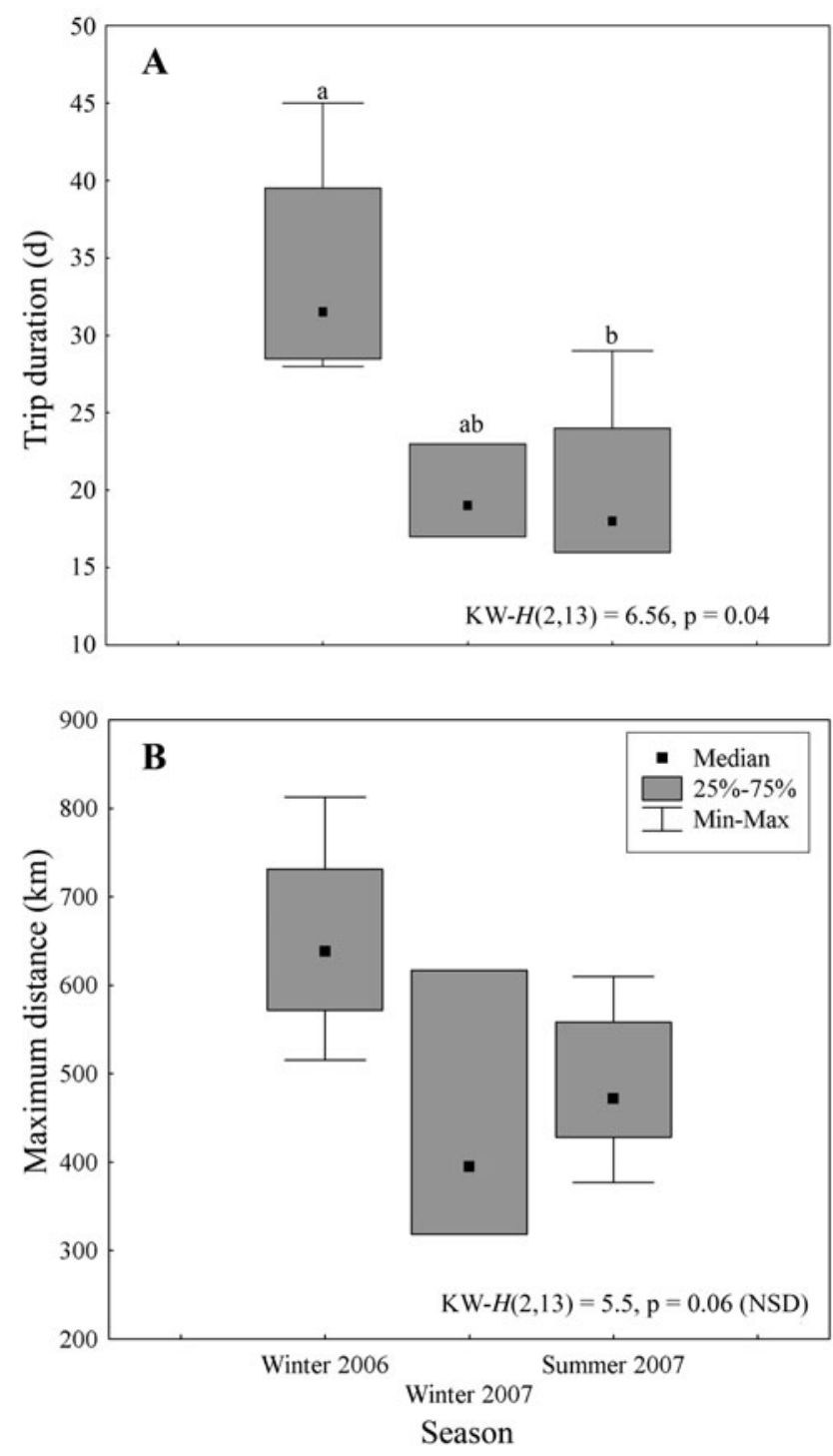

Fig. 4. Arctocephalus tropicalis. (A) Trip duration and (B) maximum distance from Marion Island reached for the 13 lactating fur seals that completed trips, instrumented at Marion Island over the 3 different deployment periods. The Kruskal-Wallis $H$-value is indicated in the figure, and significant differences are indicated by different letters. Significance is at $p<0.05$

antarctic fur seals. Subantarctic fur seals are capable of long-distance movements (Table 1, Fig. 2) during foraging trips, and thus the distance to the Andrew Bain Fracture Zone from the island (direct route $=430 \mathrm{~km}$ ) cannot be a limitation, and swimming upstream directly after a period of onshore fasting (but resting), is an unlikely hindrance. Alternatively, fur seals that foraged to the west of the island travelled through significantly deeper water ( 4500 m mean depth) than those travelling to the east ( $2500 \mathrm{~m}$ mean depth). Although fur seals rarely dive deeper than $200 \mathrm{~m}$ (Georges et al. 2000), the shallower benthos to the east of Marion Island (Fisher \& Goodwillie 1997) results in flow dynamics of differing bodies of water that are conducive to generating a shallow mixed layer; therefore, conditions more suitable to phytoplankton growth near the surface (Perissinotto \& McQuaid 1992, Read et al. 2007) than over the deeper benthos to the west (Ansorge \& Lutjeharms 2005). The potential for intermittent foraging during the transit phases to/from clearly defined ARMs could also explain the predominantly eastward, rather than westward, movement of the subantarctic fur seal females from the island. But why do these seals forage so far from Marion Island despite the island's location within the seemingly productive PFZ (Froneman et al. 1999, Bernard et al. 2007)? Indeed, this finding is contrary to the foraging ecology of subantarctic fur seals at both îles Crozet and Macquarie Island.

\section{Diet and between-island intra-species comparisons}

Kirkman et al. (2002) found lengthy absences at sea for lactating subantarctic fur seals, between pup attendance sessions, but could not elaborate on the reasons for such long absences without concurrent at-sea movement data. The present study confirms that subantarctic fur seal females at Marion Island undertake equally lengthy foraging trips, as has been shown for Amsterdam Island fur seals (Beauplet et al. 2004). The Marion Island fur seals do not feed inshore and do not make overnight foraging trips, in contrast to fur seal behaviour during summer at the neighbouring îles Crozet (Bailleul et al. 2005, Luque et al. 2007) and at Macquarie Island, which is located at a comparable latitude (Robinson et al. 2002).

The weaning masses of male and female pups from several Marion Island colonies were similar during 2006 and 2007 (M. N. Bester unpubl. data) and were comparable with previous years (Kirkman et al. 2002), indicating that foraging success rates (associated with at-sea movements) during these years were not anomalous. All pups of tracked mothers that returned, weaned successfully. Scat analyses in the present study indicated no distinct changes in the species composition of the predominantly myctophid fish diet, over the present study period or that of a previous study (Klages \& Bester 1998). However, the relative contributions of the most important species in the diet, Gymnoscopelus bolini, G. piabilis and G. nicholsi, were markedly different to those in the latter study. The temporally restricted sampling in the present study $(\sim 1 \mathrm{yr})$ compared with that in the previous study (5 yr pooled) precludes adequate explanation of this result. Limited seasonal variation in the relative importance in species consumption is evident here. The period of 

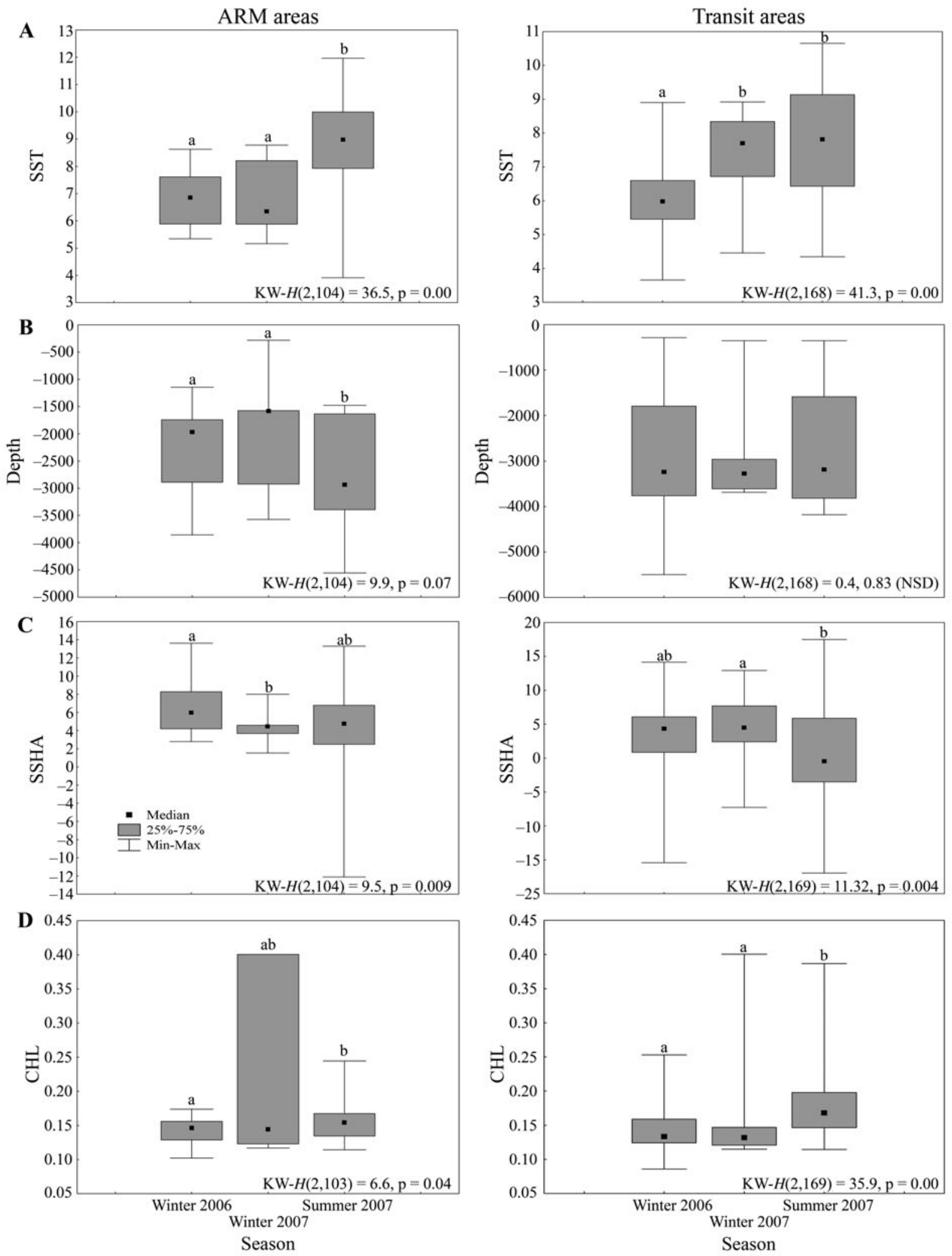

Fig. 5. Environmental characteristics: (A) sea-surface temperature ( $\left.\mathrm{SST}^{\circ}{ }^{\circ} \mathrm{C}\right),(\mathrm{B})$ bathymetry $(\mathrm{m}),(\mathrm{C})$ sea-surface height anomaly $\left(\mathrm{SSHA}_{;} \mathrm{cm}\right)$ and $(\mathrm{D})$ chlorophyll a concentration $\left(\mathrm{chl} a_{1} \mathrm{mg} \mathrm{m}^{-3}\right.$ ) encountered for the areas of restricted movement (ARMs) and transit locations during each season. The Kruskal-Wallis $H$-value is indicated in the figure, and significant differences are indicated by different letters. Significance is at $\mathrm{p}<0.05$ 
Table 2. Arctocephalus tropicalis. Percentage frequency of occurrence (FO\%), percentage numerical abundance (NA\%) and percentage mass (Mass\%) contribution of prey (Myctophidae) identified in scats ( $\mathrm{n}=192)$ collected from A. tropicalis at Marion Island, divided into 3 seasons (see 'Materials and methods')

\begin{tabular}{|c|c|c|c|c|c|c|c|c|c|}
\hline \multirow[t]{2}{*}{ Species of prey } & \multicolumn{3}{|c|}{ Winter $2006(\mathrm{n}=24)$} & \multicolumn{3}{|c|}{ Summer $2007(n=49)$} & \multicolumn{3}{|c|}{ Winter $2007(\mathrm{n}=119)$} \\
\hline & $\mathrm{FO} \%$ & NA $\%$ & Mass $\%$ & $\mathrm{FO} \%$ & NA $\%$ & Mass \% & $\mathrm{FO} \%$ & NA $\%$ & Mass $\%$ \\
\hline Electrona antarctica & 4.17 & 0.23 & 0.01 & 13.04 & 0.65 & 0.04 & 3.88 & 0.55 & 0.03 \\
\hline Electrona carlsbergi & 8.33 & 1.61 & 0.22 & 24.44 & 2.97 & 0.54 & 25.24 & 3.21 & 0.69 \\
\hline Electrona subaspera & 41.67 & 28.97 & 7.23 & 31.11 & 3.36 & 1.72 & 47.57 & 6.08 & 2.23 \\
\hline Gymnoscopelus bolini & 70.83 & 41.15 & 73.19 & 86.67 & 24.76 & 76.74 & 65.05 & 18.48 & 45.28 \\
\hline Gymnoscopelus braueri & 4.17 & 0.92 & 1.82 & 4.44 & 0.13 & 0.38 & 3.88 & 0.20 & 3.20 \\
\hline Gymnoscopelus fraseri & 20.83 & 4.60 & 0.97 & 53.33 & 5.30 & 1.22 & 50.49 & 33.13 & 7.43 \\
\hline Gymnoscopelus nicholsi & 50.00 & 7.82 & 8.26 & 73.33 & 10.73 & 13.81 & 64.08 & 11.41 & 13.25 \\
\hline Gymnoscopelus piabilis & 16.67 & 2.30 & 5.73 & 4.44 & 0.32 & 0.79 & 36.89 & 7.92 & 22.53 \\
\hline Krefftichthys anderssoni & 8.33 & 0.69 & 0.01 & 80.00 & 11.51 & 0.21 & 47.57 & 9.94 & 1.96 \\
\hline Lampichthys procerus & 0.00 & 0.00 & 0.00 & 8.89 & 0.32 & 0.12 & 2.91 & 0.38 & 0.82 \\
\hline Metelectrona ventralis & 29.17 & 8.74 & 2.49 & 46.67 & 10.92 & 3.56 & 41.75 & 5.81 & 1.75 \\
\hline Protomyctophum bolini & 0.00 & 0.00 & 0.00 & 6.67 & 0.19 & 0.01 & 3.88 & 0.14 & 0.01 \\
\hline Protomyctophum choriodon & 0.00 & 0.00 & 0.00 & 20.00 & 1.42 & 0.20 & 4.85 & 0.27 & 0.06 \\
\hline Protomyctophum tenisoni & 12.50 & 2.99 & 0.06 & 46.67 & 27.41 & 0.68 & 17.48 & 2.49 & 0.74 \\
\hline Unidentified squid & 0.16 & 6.67 & - & 40.81 & 4.20 & - & 0.14 & 1.20 & - \\
\hline
\end{tabular}

later lactation during 2007 (autumn/winter-coincident with predominantly due east foraging distribution from the island, rather than northeast as in 2006W; Figs. 2 \& 3), as compared to earlier (2007S) lactation, showed markedly increased consumption of $G$. piabilis and G. nicholsi in relation to G. bolini, although the latter remained a dominant component. The high energy content and size of $G$. piabilis may result in this species being preferred by seals when available (e.g. during late gestation) (Lea et al. 2002). Despite the species composition of the diet identified here being superficially similar to that identified at Îles Crozet, the relative contribution of $G$. piabilis (and particularly $G$. fraseri) there dwarfs that of G. bolini and G. nicholsi during the summer (Luque et al. 2007). At Macquarie Island, the predominant prey component is Electrona subaspera (Robinson et al. 2002), which is unimportant in terms of mass contribution at Marion Island, albeit frequently encountered in scats. The fish species consumed at Marion Island (and by the fur seals from the other islands within the PFZ) differ from those preyed upon at Amsterdam Island, although the most important prey at all sites are mesopelagic fish from the family Myctophidae (Robinson et al. 2002, Beauplet et al. 2004, Luque et al. 2007). Clearly, based on satellitetracking and dietary data, lactating fur seals from Amsterdam, Macquarie and Marion islands do not feed in overlapping areas (due to the vast distances between these islands). However, at all sites, the fur seals appear to seek similar oceanographic anomalies, presumed to be the ideal habitat for the seals' preferred prey, myctophids. Even the fur seals from Marion Island and the neighbouring Îles Crozet (the diets of which are more similar in species composition), which are more likely to utilise similar foraging areas, are spatially separated (Bailleul et al. 2005, Luque et al. 2007). However, the Îles Crozet animals were only tracked in summer, when they remain within the limits of the Crozet archipelago. Complex interactions between frontal systems, bathymetry and biological oceanographic features may explain why the Îles Crozet fur seals feed close to their island rookeries and Marion Island seals do not.

\section{Environmental linkages and long-distance movements}

Downstream (to the east) of Marion Island substantial mixing of warmer SAF and colder APF water takes place (Perissinotto \& McQuaid 1992, Ansorge et al. 1999). Together with some Marion Island nutrient runoff (Perissinotto et al. 2000), this creates an area conducive to phytoplankton growth and zooplankton assemblages from cooler and warmer waters (Perissinotto \& McQuaid 1992). The fur seals that headed to the east and northeast of Marion Island appeared to focus their foraging phases (ARMs) in areas corresponding to several clustered bathymetric features, including the Bob Fisher Ridge, John Harrison Ridge, Discovery II Fracture Zone and, especially, the Del Caño Rise (Fig. 3). The Del Caño Rise is associated with the development of eddies, forming due to the interaction of large-scale circulation with sub-mesoscale structure, with annual phytoplankton blooms occurring in this vicinity as a result (Pollard et al. 2007, Read et al. 2007, Venables et al. 2007). A meander in a filament of the SAF between the Del Caño Rise to the 
west and the Crozet Plateau to the east, resulting in the formation of eddies, is responsible for the entrainment of nutrient-rich water from the SAF into the associated bloom area (Read et al. 2007). The Del Caño Rise and Crozet Plateau form obstacles in the path of the SAF, causing weak circulation in the PFZ between the SAF and Îles Crozet and allowing dissolved iron and sediments from the Crozet Plateau and Islands to build up during winter. This situation (Pollard et al. 2007), augmented by the complex shape of these islands (Pollard et al. 2007, Read et al. 2007, Venables et al. 2007), gives rise to the characteristic annual phytoplankton blooms. These productive blooms probably explain why sympatric Antarctic and subantarctic fur seals from the Crozet Archipelago feed in the vicinity of their breeding colony beaches (50 to $100 \mathrm{~km}$ ) and undertake overnight foraging trips (Bailleul et al. 2005, Luque et al. 2007), in contrast to the Marion Island subantarctic fur seals that range far and wide (present study). This difference could be due to the proximity of the SAF and APF to Marion Island, which cause fast flow of the water masses past the island, hindering the build-up of chlorophyll in entrained water near the island (Hunt et al. 2001). The absence of large bathymetric features immediately to the west of the island (disregarding the more distant Andrew Bain Fracture Zone) and the islands' simple (approximately oval) shape facilitate this fast flow. Thus, despite similar latitudinal location to Îles Crozet, which suggests that Marion Island seals should also make short foraging trips owing to their location within the productive PFZ, regional bathymetric features may explain why seals from Marion Island travel further from their breeding colonies (as with the Amsterdam Island fur seals).

Subantarctic fur seals at Amsterdam Island undertake extremely long winter foraging trips $(>1000 \mathrm{~km}$; $\sim 30$ d) to the east or south-east, which appears partially linked to the migration of the STF (Georges et al. 2000, Beauplet et al. 2004). At Marion Island they seem to be more dependent on the SAF, which migrates north in winter and south in summer, also resulting in longer winter foraging trips for the Marion Island fur seals (>800 km; $\sim 30 \mathrm{~d}$ ). However, our sample size is small, and individual variation may have an influence on results. It is perhaps significant that the only southerly foraging trip from Marion Island occurred during summer, which would coincide with a more southerly migration of the SAF. Biotic changes since 1976 suggest that the SAF, known to have a high degree of variability, may have moved southwards towards Marion Island (Pakhomov et al. 2000). Both the SAF and the APF have steep physical gradients (Lutjeharms 1985), which represent vital biogeographic limits (Pakhomov et al. 1994, Tarling et al. 1995), and are zones of enhanced biological activity (Lutjeharms 1985, Hunt et al. 2001). Such variations in SSTs shape the distribution and abundance of zooplankton (Pakhomov et al. 1994), fish, squid and ultimately top marine predators (Beauplet et al. 2004). Therefore, southward movement of the SAF is likely to be responsible for the reduction in mesozooplankton biomass in waters adjacent to Marion Island, producing a bottom-up effect on top-predator populations (Hunt et al. 2001). A local depletion of mesozooplankton biomass around Marion Island could further contribute to the long-distance foraging trips undertaken by lactating fur seals to the bathymetrically influenced oceanographic environments around the Del Caño Rise.

\section{Ecological implications}

The present study illustrates that, despite the supposedly preferable location of Marion Island on the productive PFZ, the regional bathymetric influences on large-scale frontal systems appear to be of greater importance to local top predators than the mere proximity of such frontal systems to the island. Perhaps, then, the Marion Island fur seals do not have an easier time of finding prey than their Amsterdam Island longdistance travelling counterparts, with implications for similar bottom-up control of these populations. However, the local roles of competition with sympatric Antarctic fur seals and large penguin populations (Crawford et al. 2003) and of predation pressure by locally abundant killer whales at Marion Island (Tosh et al. 2008) remains to be explored. Killer whales at Marion Island are known to predate on seals and penguins (Condy et al. 1978) and are possibly an important determinant of inshore movements of seals. The foraging overlap by the 2 sympatric fur seal species at îles Crozet does not appear to be functionally competitive (Bailleul et al. 2005, Luque et al. 2007), although the much larger populations of these 2 species at Marion Island (Hofmeyr et al. 2006) may result in some competition. Therefore, while the foraging ecology of Marion Island subantarctic fur seals appears to be chiefly dictated by the spatial availability of the preferred prey (myctophids) within the region, the roles of interspecific competition and/or killer whale predation pressure needs investigation to further understand the foraging choices that these fur seals make.

Acknowledgements. The Department of Environmental Affairs and Tourism provided logistical support within the South African National Antarctic Programme. Financial support was provided by the Department of Science and Technology, through the National Research Foundation (NRF), in support of the Marine Mammal Programme of the MRI. During the compilation of this paper both P.J.N.dB. and W.C.O. benefitted from NRF Grantholder-linked bursaries within the 
project 'Conservation of Seabirds, Shorebirds and Seals' led by L. Underhill of the Animal Demography Unit, Department of Zoology, University of Cape Town. We thank J. A. Ramunasi for assistance with otolith identification and V. M. Phalanndwa for field assistance in 2007. We thank the 3 anonymous reviewers whose comments led to significant improvements in the manuscript. All of the above procedures have ethics clearance from the Animal Use and Care Committee (AUCC) of the Faculty of Natural and Agricultural Sciences, University of Pretoria, South Africa, under AUCC 040827-023.

\section{LITERATURE CITED}

Ansorge IJ, Lutjeharms JRE (2005) Direct observations of eddy turbulence at a ridge in the Southern Ocean. Geophys Res Lett 32:L14603 doi:10.1029/2005GL022588

Ansorge IJ, Froneman PW, Pakhomov EA, Lutjeharms JRE, Perissinotto R, van Ballegooyen RC (1999) Physical-biological coupling in the waters surrounding the Prince Edward Islands (Southern Ocean). Polar Biol 21:135-145

Bailleul F, Luque S, Dubroca L, Arnould JPY, Guinet C (2005) Differences in the foraging strategy and maternal behaviour between two sympatric fur seal species at the Crozet Islands. Mar Ecol Prog Ser 293:273-282

Beauplet G, Dubroca L, Guinet C, Cherel Y, Dabin W, Gagne C, Hindell M (2004) Foraging ecology of subantarctic fur seals Arctocephalus tropicalis breeding on Amsterdam Island: seasonal changes in relation to maternal characteristics and pup growth. Mar Ecol Prog Ser 273:211-225

- Beauplet G, Barbraud C, Chambellant M, Guinet C (2005) Interannual variation in the post-weaning and juvenile survival of subantarctic fur seals: influence of pup sex, growth rate, and oceanographic conditions. J Anim Ecol 74:1160-1172

Bernard ATF, Ansorge IJ, Froneman PW, Lutjeharms JRE, Bernard KS, Swart NC (2007) Entrainment of Antarctic euphausiids across the Antarctic Polar Front by a cold eddy. Deep-Sea Res I 54:1841-1851

> Bester MN (1989) Movements of southern elephant seals and subantarctic fur seals in relation to Marion Island. Mar Mamm Sci 5:257-265

Bester MN, Bartlett PA (1990) Attendance behaviour of Antarctic and subantarctic fur seal females at Marion Island. Antarct Sci 2:309-312

Bester MN, Van Jaarsveld AS (1994) Sex-specific and latitudinal variance in postnatal growth of the subantarctic fur seal (Arctocephalis tropicalis). Can J Zool 72:1126-1133

Bester MN, Ryan PG, Dyer BM (2003) Population numbers of fur seals at Prince Edward Island, Southern Ocean. Afr J Mar Sci 25:549-554

Biuw M, Boehme L, Guinet C, Hindell M and others (2007) Variations in behaviour and condition of a southern ocean top predator in relation to in situ oceanographic conditions. Proc Natl Acad Sci USA 104:13705-13710

Block BA (2005) Physiological ecology in the 21st century: advancements in biologging science. Integr Comp Biol 45: 305-320

Bonadonna F, Lea MA, Guinet C (2000) Foraging routes of Antarctic fur seals (Arctocephalus gazella) investigated by concurrent use of satellite tracking and time-depth recorders. Polar Biol 23:149-159

Bost CA, Cotté C, Bailleul F, Cherel Y and others (2009) The importance of oceanographic fronts to marine birds and mammals of the southern oceans. J Mar Syst 78:327-336 doi:10.1016/j.jmarsys.2008.11.022
Boyd IL, McCafferty DJ, Walker TR (1997) Variation in foraging effort by lactating Antarctic fur seals: response to simulated increased foraging costs. Behav Ecol Sociobiol 40: 135-144

- Cherel Y, Hobson KA, Guinet C, Vanpe C (2007) Stable isotopes document seasonal changes in trophic niches and winter foraging individual specialization in diving predators from the Southern Ocean. J Anim Ecol 76:826-836

Ciannelli L, Robson BW, Francis RC, Aydin K, Brodeur RD (2004) Boundaries of open marine ecosystems: an application to the Pribilof Archipelago, Southeast Bering Sea. Ecol Appl 14:942-953

> Condy PR, van Aarde RJ, Bester MN (1978) The seasonal occurrence and behaviour of killer whales Orcinus orca, at Marion Island. J Zool 184:449-464

> Constable AJ, Nicol S, Strutton PG (2003) Southern Ocean productivity in relation to spatial and temporal variation in the physical environment. J Geophys Res 108(C4):8079 doi:10.1029/2001JC001270

Crawford RJM, Cooper J, Dyer BM, Greyling MD and others (2003) Populations of surface-nesting seabirds at Marion Island, 1994/95-2002/03. Afr J Mar Sci 25:427-440

de Bruyn PJN, Bester MN, Mecenero S, Kirkman SP, Roux JP, Klages NTW (2003) Temporal variation of cephalopods in the diet of Cape fur seals in Namibia. S Afr J Wildl Res 33: 83-96

ESRI (Environmental Systems Research Institute) (1998) Arc and grid command references. ESRI, Redlands, CA

Fedak MA (2004) Marine animals as platforms for oceanographic sampling: a 'win/win' situation for biology and operational oceanography. Mem Natl Inst Polar Res (Jpn) 58:133-147

Feldman GC, McClain CR (2008a) Aqua MODIS sea surface temperature. In: Kuring N, Bailey SW, Thomas D, Franz $\mathrm{BF}$ and others (eds) Ocean color web. NASA Goddard Space Flight Center, Greenbelt, MD. Available at: http:// oceancolor.gsfc.nasa.gov/cgi/l3

Feldman GC, McClain CR (2008b) Aqua MODIS monthly chlorophyll concentration. In: Kuring N, Bailey SW, Thomas D, Franz BF and others (eds) Ocean color web. NASA Goddard Space Flight Center, Greenbelt, MD. Available at: http://oceancolor.gsfc.nasa.gov/cgi/l3

Ferreira SM, Bester MN (1998) Chemical immobilization, physical restraint and stomach lavaging of fur seals at Marion Island. S Afr J Wildl Res 29:55-61

- Fisher RL, Goodwillie AM (1997) The physiography of the Southwest Indian Ridge. Mar Geophys Res 19:451-455

> Froneman PW, McQuaid CD, Laubscher RK (1999) Size-fractionated primary production studies in the vicinity of the Subtropical Front and an adjacent warm-core eddy south of Africa in austral winter. J Plankton Res 21:2019-2035

> Georges JY, Tremblay Y, Guinet C (2000) Seasonal diving behaviour in lactating subantarctic fur seals on Amsterdam Island. Polar Biol 23:59-69

Hofmeyr GJG, Bester MN, Makhado AB, Pistorius PA (2006) Population changes in subantarctic and Antarctic fur seals at Marion Island. S Afr J Wildl Res 36:55-68

Hofmeyr GJG, Bester MN, Pistorius PA, Mulaudzi TW and others (2007) Median pupping date, pup mortality and sex ratio of fur seals at Marion Island. S Afr J Wildl Res 37:1-8

Hoodge PN, Eichenlaub B (1997) Animal movement extension for Arcview, Ver. 1.1. Alaska Science Center-Biological Science Office, US Geological Survey, Anchorage, AK

> Hunt BPV, Pakhomov EA, McQuaid CD (2001) Short-term variation and long-term changes in the oceanographic environment and zooplankton community in the vicinity of a sub-Antarctic archipelago. Mar Biol 138:369-381 
IOC IHO, BODC (Intergovernmental Oceanographic Commission and the International Hydrographic Organisation, General Bathymetric Chart of the Oceans; British Oceanographic Data Centre) (2003) Centenary edition of the GEBCO digital atlas, CD-ROM. IOC IHO, BODC, Liverpool

Jonker FC, Bester MN (1998) Seasonal movements and foraging areas of adult southern female elephant seals, Mirounga leonina, from Marion Island. Antarct Sci 10: 21-30

Kerley GIH (1983) Relative population sizes and trends, and hybridisation of fur seals Arctocephalus tropicalis and A. gazella at Prince Edward Islands, Southern Ocean. S Afr J Zool 18:388-392

Kerley GIH (1985) Pup growth in the fur seals Arctocephalus tropicalis and A. gazella on Marion Island. J Zool 205: $315-324$

Kirkman SP, Bester MN, Hofmeyr GJG, Pistorius PA, Makhado AB (2002) Pup growth and maternal attendance patterns in subantarctic fur seals. Afr Zool 37:13-19

Kirkman SP, Bester MN, Makhado AB, Pistorius PA (2003) Female attendance patterns of Antarctic fur seals at Marion Island. Afr Zool 38:402-405

Klages NTW, Bester MN (1998) The fish prey of fur seals Arctocephalus spp. at subantarctic Marion Island. Mar Biol 131:559-566

Lea MA, Dubroca L (2003) Fine-scale linkages between the diving behaviour of Antarctic fur seals and oceanographic features in the southern Indian Ocean. ICES J Mar Sci 60: 990-1002

Lea MA, Nichols PD, Wilson G (2002) Fatty acid composition of lipid-rich myctophids and mackerel icefish (Champsocephalus gunnari) - Southern Ocean food-web implications. Polar Biol 25:843-854

Lea MA, Guinet C, Cherel Y, Duhamel G, Dubroca L, Pruvost P, Hindell M (2006) Impacts of climatic anomalies on provisioning strategies of a Southern Ocean predator. Mar Ecol Prog Ser 310:77-94

Lea MA, Guinet C, Cherel Y, Hindell M, Dubroca L, Thalmann S (2008) Colony-based foraging segregation by Antarctic fur seals at the Kerguelen Archipelago. Mar Ecol Prog Ser 358:273-287

Luque SP, Arnould JPY, Miller EH, Cherel Y, Guinet C (2007) Foraging behaviour of sympatric Antarctic and subantarctic fur seals: Does their contrasting duration of lactation make a difference? Mar Biol 152:213-224

Lutjeharms JRE (1985) Location of frontal systems between Africa and Antarctica; some preliminary results. Deep-Sea Res 32:1499-1509

Lutjeharms JRE, Valentine HR (1984) Southern Ocean thermal fronts south of Africa. Deep-Sea Res 31:1464-1476

Lutjeharms JRE, Valentine HR (1988) Eddies at the sub-tropical convergence south of Africa. J Phys Oceanogr 18:761-774

Makhado AB, Bester MN, Kirkman SP, Pistorius PA, Ferguson JWH, Klages NTW (2008) Prey of the Antarctic fur seal Arctocephalus gazella at Marion Island. Polar Biol 31: 575-581

- McCafferty DJ, Boyd IL, Walker TR, Taylor RI (1998) Foraging responses of Antarctic fur seals to changes in the marine environment. Mar Ecol Prog Ser 166:285-299

Nel DC, Lutjeharms JRE, Pakhomov EA, Ansorge IJ, Ryan PG, Klages NTW (2001) Exploitation of mesoscale oceano-

Editorial responsibility: Yves Cherel,

Villiers-en-Bois, France graphic features by grey-headed albatrosses Thalassarche chrysostoma in the southern Indian Ocean. Mar Ecol Prog Ser 217:15-26

Orians GH, Pearson NE (1979) On the theory of central place foraging. In: Horn DJ, Stairs GR, Mitchell RD (edrs) Analysis of ecological systems. Ohio State University Press, Columbus, OH, p 155-177

Osbourne RF, Naidoo AD, Verheye HM (eds) (2002) Research highlights 2001-2002. Marine \& Coastal Management, Cape Town

Pakhomov EA, Perissinotto R, McQuaid CD (1994) Comparative structure of the macrozooplankton/micronecton communities of the Subtropical and Antarctic Polar Fronts. Mar Ecol Prog Ser 111:155-169

Pakhomov EA, Froneman PW, Ansorge IJ, Lutjeharms JRE (2000) Temporal variability in the physico-biological environment of the Prince Edward Islands (Southern Ocean). J Mar Syst 26:75-95

Perissinotto R, McQuaid CD (1992) Land-based predator impact on vertically migrating zooplankton and micronekton advected to a Southern Ocean archipelago. Mar Ecol Prog Ser 80:15-27

> Perissinotto R, Lutjeharms JRE, van Ballegooyen RC (2000) Biological-physical interactions and pelagic productivity at the Prince Edward Islands, Southern Ocean. J Mar Syst 24:327-341

> Pollard RT, Venables HJ, Read JF, Allen JT (2007) Large-scale circulation around the Crozet Plateau controls an annual phytoplankton bloom in the Crozet Basin. Deep-Sea Res II 54:1915-1929

Read JF, Pollard RT, Allen JT (2007) Sub-mesoscale structure and the development of an eddy in the subantarctic front north of the Crozet Islands. Deep-Sea Res II 54: 1930-1948

Robinson SA, Goldsworthy SG, Van den Hoff J, Hindell MA (2002) The foraging ecology of two sympatric fur seal species, Arctocephalus gazella and Arctocephalus tropicalis, at Macquarie Island during the austral summer. Mar Freshw Res 53:1071-1082

Seaman DE, Powell RA (1996) An evaluation of the accuracy of kernel density estimators for home range analysis. Ecology 77:2075-2085

Silverman ED (1986) Density estimation for statistics and data analysis. Chapman \& Hall, London

> Tarling GA, Ward P, Sheader M, Williams JA, Symon C (1995) Distribution patterns of macrozooplankton assemblages in the southwest Atlantic. Mar Ecol Prog Ser 120:29-40

Tosh CA, de Bruyn PJN, Bester MN (2008) Preliminary analysis of the social structure of killer whales, Orcinus orca, at subantarctic Marion Island. Mar Mamm Sci 24:929-940

Tosh CA, Bornemann H, Ramdohr S, Schröder M and others (2009) Adult male southern elephant seals from King George Island utilize the Weddell Sea. Antarct Sci 21: 113-121

Venables HJ, Pollard RT, Popova EK (2007) Physical conditions controlling the development of a regular phytoplankton bloom north of the Crozet Plateau, Southern Ocean. Deep-Sea Res II 54:1949-1965

White NA, Sjöberg M (2002) Accuracy of satellite positions from free-ranging grey seals using ARGOS. Polar Biol 25: $629-631$

Submitted: December 5, 2008; Accepted: August 31, 2009 Proofs received from author(s): November 6, 2009 